Ann. Génét. Sél. anim., I972, 4 (2), 225-228.

\title{
THE POSSIBILITY TO AVOID IRREGULAR OVIPOSITIONS BY MEANS OF SEX-LINKED DWARFISM ( $\left.{ }^{1}\right)$
}

\author{
A. R. KUIT and J. H. van MIDDELKOOP \\ Spelderholt, Institute for Poultry Research, \\ Beekbergen, The Netherlands
}

\section{SUMMARY}

Irregular ovipositions are more found in broiler-mothers than in layers. Two eggs laid on the same day accounted for 0,8 to 6,2 per cent of yolks from broiler-type as compared with $0, x$ per cent to 2,0 per cent from egg-type pullets in different strains at the beginning of the laying period (JAAP and MUIR, I968).

The present research indicates that the bigger part of the eggs laid within 20 hours have a peculiar kind of abnormality due to the presence of two eggs in the shell gland. These eggs as a group have a very poor hatchability.

Possibilities of a regulating effect of sex-linked dwarfism on oviposition will be discussed.

The interest in the dwarf-gene originates from the work the Institute carries out on the productivity of broiler mothers.

In order to be able to study things like clutch size, and the length of laying intervals, a strain of White Plymouth Rock hens was housed in single cages, so that every egg could be registered, the influence of nesting behaviour being avoided in this way. Very soon we made the same observations as JAAP and others, namely that these heavy birds lay a large number of abnormal eggs.

a) double yolked eggs ;

b) membranous eggs of normal shape ;

c) soft-shelled eggs of normal shape;

d) membranous eggs with a flattened area;

(1) Presented to the Symposium on the Dwarf Gene in Domestic Fowl, Tours, France, March 4 and 5 , I97I, under the auspices of the Station de Recherches avicoles, Nouzilly, Institut national de la Recherche agronomique

An english summary of this paper has been printed in World's Poultry Sci., 1971, 27, 282-283, a french summary in the present journal ( $A$ nn. Gémét. Sél. anim.. I97r, 3,) under the single name of A. R. Kuit. 
e) more or less soft-shelled eggs with a flattened area ;

f) shell eggs which have partly an additional calcification;

g) more or less soft-shelled eggs with a bulge ;

h) eggs of normal shape with yolk material on the outside.

From a study on this subject by VAN MIDDELKOOP and SimONS - the results of which were communicated in Madrid last year - it became clear that the presence of two eggs at the same time in the shell gland is responsible for many abnormal eggs and for a strange laying pattern.

In contrast with the double yolked eggs, the phenomenon of two eggs a day - or rather two eggs within 20 hours - is not more or less restricted to the first months of lay, but is found throughout the whole laying period. The usual pattern is that the fiist egg stays in the shell gland for too long a time and is laid in the evening up to a few hours before midnight. This is about half a day after the expected time of oviposition. The second shell egg is laid about I $_{5}$ hours after the first one.

The first egg has a hard shell, which is partly additionally calcified. This extra calcification is usually situated in the form of a band over a part of the shell.

The second egg which is more or less soft-shelled, has a typical abnormality : it usually has a flattened area, which is thinner than the rest of the shell and which is surrounded by a ring of wrinkled shell.

Examples of a normal laying pattern and of four abnormal patterns are given in the figures I and 2.

The patterns can be very irregular. In our strain last year about 38 p. roo of the hens never laid two eggs a day while $47 \mathrm{p}$. Ioo did so less than or equal to five times a year and 15 p. Ioo more than five times a year.

The hatchability of the so called first eggs is very poor. Depending on the amount and the area of extra calcification 2-I2 p. Ioo of the fertile ones gave a chick, against 82 p. roo in the controls. The second eggs are usually lost, because most of them are broken during gathering and transport. When not broken and if the evaporation is not too high, they will hatch as well as normal eggs. Usually the hatchery operator refuses them however on account of their compressed shape.

Irregular times of oviposition were observed and as far as is known at the moment are induced by the irregular length of the interval between two succeeding ovulations within a clutch.

Many deviations in egg production are the consequence of a disharmony in the time between the successive ovulations and the duration necessary for the formation of the complete egg. Our investigation showed that the expected oviposition does not take place when the next ovulation occurs more than about five hours before this time. In this case the oviposition is delayed, resulting in an irregular laying pattern and in the laying of two abnormal eggs. Such ovulations succeeding each other rapidly, will also however - in a smaller number of cases - cause a too early expulsion of the preceeding egg.

In our view a short interval between ovulations is related to a relatively large number of follicles in the ovarium being in the rapid growing phase. When more follicles at the same time are in the above phase there is a bigger chance that the difference in maturity between successive follicles is not large enough.

JaAp and Mohammadian (I969) stated in a publication that breeding for the 
gene $d w$ leads to a reduced number of follicles in the rapid growing phase in the ovarium.

Due to this reduction we assume that the chance of two succeeding follicles having too small a difference in maturity is diminished.

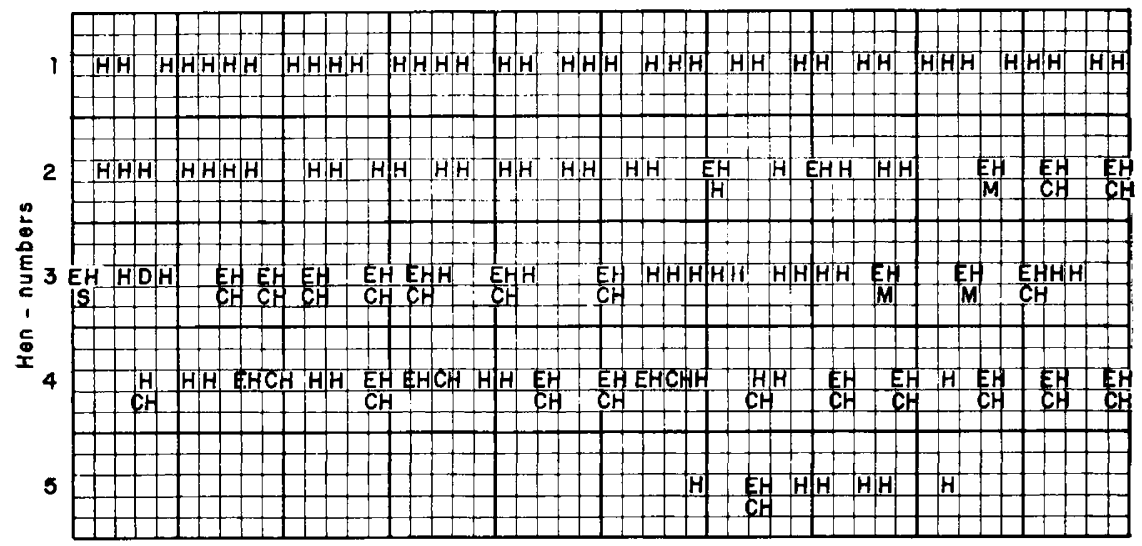

FIG. I. - Laying' pattern of 5 hens during the fourth and fifth month of the laying period

Code $: \mathrm{H}=$ normal Hard shelled egg.

$\mathrm{EH}=$ Hard shelled egg with Extra calcification on the surface

$\mathrm{CH}=$ Hard shelled egg with a Compressed side

$\mathrm{S}=$ Soft shelled egg

$\mathbf{M}=$ Membranous egg

$\mathrm{D}=$ Double yolked egg.

Fig. I. - Rythme de ponte de 5 poules pendant le $4^{\theta}$ et le $5^{\mathrm{e}}$ mois de ponte

Code $: \mathrm{H}=$ Euf normal à coquille solide.

$\mathrm{EH}=$ Euf à coquille solide avec extra- calcification sur la coquille.

$\mathrm{CH}=$ Euf à coquille solide avec compression d'un côté.

$\mathbf{S}=$ Cuf à coquille molle.

$\mathbf{M}=$ Euf membraneux.

$\mathrm{D}=$ Euf à double jaune.

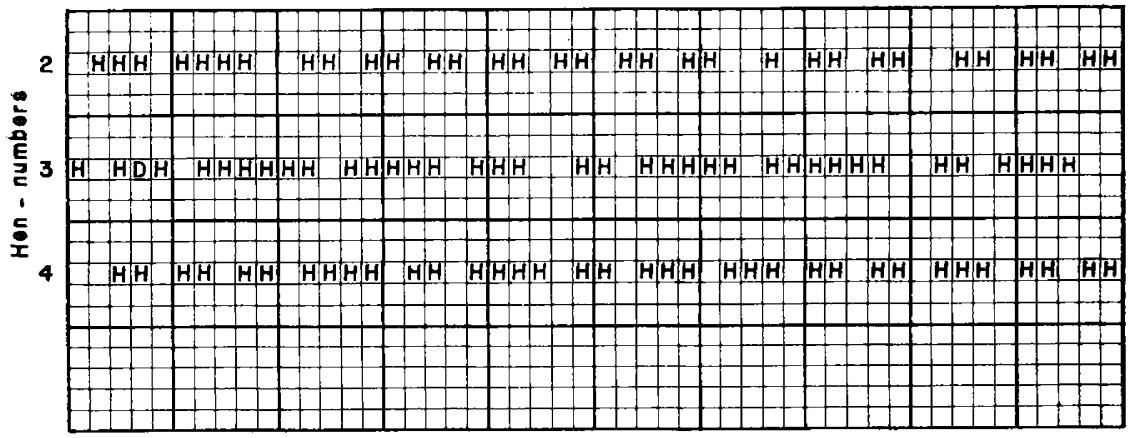

FIG. 2. - Pattern if " $E H$ " had been laid on the normal expected time

Frg. 2. - Rythme de ponte si les aeufs " $E H$ " avaient été pondus au moment normalement prévu

The rapidly succeeding ovulation should occur a few hours later in order to result in the laying of normal eggs without changing the laying pattern. This line of reasoning makes it possible - at least partly - to explain why in broiler strains 
the gene $d w$ does not necessarily need to lead to a decreased normal egg production, while in laying strains it does. In laying strains - according to JAAP and CLANCY (I968) - much less follicles are in the rapid growing phase.

From a practical as well as from a theoretical point of view it is interesting to know the influence of sex-linked dwarfism on the different kinds of abnormal eggs.

\section{RÉSUMÉ}

\section{LA POSSIBILITÉ D'ÉVITER DES OVIPOSITIONS IRRÉGULIÈRES GRÂCE AU NANISME LIÉ AU SEXE}

Des ovipositions irrégulières sont plus fréquentes chez les mères de type " chair " que chez les pondeuses. Deux œufs pondus le même jour rendent compte de 0,8 à 6,2 p. Ioo des jaunes pour les types " broiler ", comparés à o, I à 2,0 p. Ioo pour des poulettes de type "pondeuse ", dans différentes lignées, au début de la période de ponte (JAAP et MUIR, I968).

Des recherches de Van MidDEL KOop à l'Institut de Recherches avicoles Spelderholt indiquent que la majorité des œufs pondus à moins de 20 heures d'intervalle présente une anomalie particulière due à la présence de deux œufs dans la glande coquillière. Ces œufs ont dans l'ensemble une très mauvaise éclosion.

La possibilité d'un effet régulateur du gène de nanisme lié au sexe sur l'oviposition est est discutée.

\section{RÉFÉRENCES}

JAap R. G., Clancy J. A., I968. Reproductive idiosyncrasies of the broiler pullet. Proc. IIIrd. Eur Poult. Congr. 74-79.

JaAp R. G., Mohammadian M., 1969. Sex-linked dwarfism and egg production of broiler dams. Poult Sci. 48, 344-346.

JaAp R. G., Muir F. V., 1968. Erratic ovipositon and egg defects in broiler-type pullets. Poult. Sci.48, 4I7-423.

Middelkoop J. H. van, Simons P. C. M., I97o. Shell abnormalities due to the presence of two eggs in the uterus. XIVth Wld's Poult. Congr., Madrid. 